\title{
Construction of a NotI restriction map of the Streptococcus mutans genome
}

\author{
Nobuo Okahashi, ${ }^{1}$ Chiniro Sasakawa, ${ }^{2}$ Nobuhiko Okada, ${ }^{2}$ Masatoshi Yamada, ${ }^{2}$ \\ Masanosuke Yoshikawa, ${ }^{2}$ Masayuki ToKUda, ${ }^{1}$ ICHIRo TaKahashi ${ }^{1}$ and ToshihiKo Koga ${ }^{1 *}$ \\ ${ }^{1}$ Department of Dental Research, National Institute of Health, Shinagawa-ku, Tokyo 141, Japan \\ ${ }^{2}$ Department of Bacteriology, Institute of Medical Science, University of Tokyo, Minato-ku, Tokyo 108, Japan
}

(Received 15 May 1990; revised 14 July 1990; accepted 23 July 1990)

\begin{abstract}
Streptococcus mutans and Streptococcus sobrinus are the major causative organisms of human dental caries. Pulsed-field gel electrophoresis (PFG) showed that the restriction enzyme NotI produced ten and six DNA fragments from the genomes of $S$. mutans strain MT8148 and $S$. sobrinus strain 6715, respectively. The sizes of the chromosomes of $S$. mutans and $S$. sobrinus were each estimated to be about $2200 \mathrm{~kb}$. The NotI restriction map of $S$. mutans MT8148 genome was constructed by Southern blot analysis with probes that overlapped two adjacent NotI fragments. Several virulence-associated genes of $S$. mutans were placed on the NotI restriction map. In addition, unique 'fingerprints' of $S$. mutans chromosomal DNA digested with NotI were produced by PFG, and these may be useful for epidemiological studies.
\end{abstract}

\section{Introduction}

Among the mutans streptococci, Streptococcus mutans and Streptococcus sobrinus play a significant role in the development of human dental caries (Hamada \& Slade, 1980; Loesche, 1986). These organisms possess several characteristic activities which are associated with their cariogenicity: they produce a large amount of lactic acid and other acids from various sugars, synthesize waterinsoluble glucan from sucrose, and colonize human tooth surfaces in either the absence or presence of sucrose (Hamada \& Slade, 1980).

Genetic approaches have been recently introduced to analyse virulence factors of $S$. mutans and $S$. sobrinus (Curtiss, 1986; Kuramitsu, 1987). Several genes potentially involved in their cariogenicity have been cloned and characterized (Abiko et al., 1989; Barrett et al., 1987; Ferretti et al., 1987, 1988, 1989; Hanada \& Kuramitsu, 1989; Lee et al., 1988; Lunsford \& Macrina, 1986; Ogundipe \& Holt, 1989; Okahashi et al., 1989a, $b$; Sato \& Kuramitsu, 1988; Shiroza \& Kuramitsu, 1988; Shiroza et al., 1987; Sommer et al., 1987; Takahashi et al., 1989; Ueda et al., 1988). However, little is known of the overall genetic organization of these bacteria.

Abbreviations: PFG, pulsed-field gel electrophoresis; OFGE, orthogonal field alternation gel electrophoresis; CHEF, contour-clamped homogeneous field electrophoresis.
Recently, pulsed-field gel electrophoresis (PFG) was developed to separate large DNA fragments (Schwartz \& Cantor, 1984). Physical maps of several bacterial genomes have been constructed by using PFG (Bautsch, 1988; Canard \& Cole, 1989; Ely \& Gerardot, 1988; Kauc et al., 1989; Lee et al., 1989; Smith et al., 1987). Here we present a physical map of the genome of $S$. mutans MT8148 (serotype c) constructed by Southern blot analysis of restriction fragments separated by PFG.

\section{Methods}

Bacterial strains. S. mutans MT8148 (serotype $c$ ) and GS-5 (serotype c) (Ohta et al., 1989), and S. sobrinus 6715 (serotype g) were mainly used. In some experiments, $S$. mutans strains MT6801, MT6861, MT6879, Xc and Xc100L (Koga et al., 1989; Okahashi et al., 1984) were used. These strains were selected from the stock culture collection in the Department of Dental Research, National Institute of Health, Tokyo, Japan.

Preparation of DNA in agarose blocks. Chromosomal DNA of $S$. mutans and $S$. sobrinus was prepared as described by Smith \& Cantor (1987). An overnight cell culture was diluted 1:50 into Todd-Hewitt broth (Difco) supplemented with $20 \mathrm{mM}$-DL-threonine, and was grown to a density of about $2 \times 10^{9}$ cells $\mathrm{ml}^{-1}$. The cells were centrifuged, washed with $10 \mathrm{~mm}-\mathrm{Tris} / \mathrm{HCl}(\mathrm{pH} \mathrm{8.0)}$ containing $1 \mathrm{M}-\mathrm{NaCl}$, and suspended in one-fifth of the original volume in the same buffer. The bacterial suspension was mixed with an equal volume of $1 \%(w / v)$ lowgelling/melting temperature agarose (InCert agarose; FMC). The mixture was allowed to solidify in a $100 \mu \mathrm{l}$ mould to form blocks. The agarose block was put into a lysis solution $[1 \mathrm{M}-\mathrm{NaCl}, 0 \cdot 1 \mathrm{M}-\mathrm{EDTA}$, 
$10 \mathrm{mM}-\mathrm{Tris} / \mathrm{HCl}(\mathrm{pH} 8.0), 0.5 \%$ (w/v) Brij $58,0.2 \%$ (w/v) sodium deoxycholate, $0.5 \%$ (w/v) Sarkosyl (Ciba-Geigy), lysozyme (1 $\left.\mathrm{mg} \mathrm{m}^{-1}\right)$ ] (Smith \& Cantor, 1987) supplemented with $\mathrm{N}$-acetylmuramidase SG $\left(0.1 \mathrm{mg} \mathrm{ml}^{-1}\right.$; Seikagaku Kogyo). After overnight incubation at $37^{\circ} \mathrm{C}$, the agarose block was incubated in a solution of 0.25 M-EDTA (pH 8.0) containing $1 \%(\mathrm{w} / \mathrm{v})$ Sarkosyl and proteinase $\mathrm{K}$ $\left(0.1 \mathrm{mg} \mathrm{ml}^{-1}\right.$; Boehringer Mannheim) overnight at $50^{\circ} \mathrm{C}$. The block was then incubated for $4 \mathrm{~h}$ in TE buffer [ $10 \mathrm{mM}$-Tris/ $\mathrm{HCl}(\mathrm{pH} 8.0)$, 1 mM-EDTA] containing $1 \mathrm{~mm}$-phenylmethylsulphonyl fluoride, and washed four times with TE buffer.

Restriction enzyme digestion. The agarose block of DNA $(100 \mu \mathrm{l})$ was incubated for 18 h with 20 to 40 units of NotI, SfiI, ApaI, NaeI, SmaI or SacII (Toyobo) in a total volume of $400 \mu \mathrm{l}$, following the recommendations of the manufacturer. For Not $\mathrm{I}$ partial digestion, the agarose block $(100 \mu \mathrm{l})$ was incubated at $37^{\circ} \mathrm{C}$ for $18 \mathrm{~h}$ in the presence of 3 units of NotI in a total volume of $400 \mu \mathrm{l}$.

$P F G$. Both orthogonal field alternation gel electrophoresis (OFAGE; Carle \& Olson, 1984) and contour-clamped homogeneous field electrophoresis (CHEF; Chu et al., 1986) systems (Pulsaphor Plus; Pharmacia LKB Biotechnology) were used. In both systems, $1.0 \%$ $(\mathrm{w} / \mathrm{v})$ agarose gels in $1 \times$ TBE buffer [0.89 M-Tris, $0.89 \mathrm{M}$-boric acid, 2 mM-EDTA (pH 8.3)] were used at $10^{\circ} \mathrm{C}$. OFAGE gels were run at $330 \mathrm{~V}$ for 24 to $40 \mathrm{~h}$ with pulse times ranging from 2 to $60 \mathrm{~s}$, depending on the resolution range desired. CHEF gels were run at $170 \mathrm{~V}$ for $40 \mathrm{~h}$ with pulse times ranging from 10 to $60 \mathrm{~s}$. $\lambda$ DNA concatemers (Clontech) were used as the size standards.

Construction of NotI linking clones. Chromosomal DNA from $S$. mutans MT8148, prepared as described previously (Okahashi et al., $1989 a$ ), was digested with EcoRI, HindIII, PstI or BglII, and selfligated with T4 DNA ligase (Takara Shuzo). The ligated fragments which contained Not I restriction sites were then linearized with Not $\mathrm{I}$, and ligated to the NotI-digested alkaline-phosphatase-treated plasmid vector pBlueScript II (Stratagene). Escherichia coli NM522 (Stratagene) was then transformed with the plasmid and plated on LB agar (Maniatis et al., 1982) containing ampicillin $\left(50 \mu \mathrm{g} \mathrm{ml}^{-1}\right)$, 5-bromo4-chloro-3-indolyl $\beta$-D-galactopyranoside $\left(40 \mu \mathrm{g} \mathrm{ml}^{-1}\right)$ and isopropyl $\beta$-D-thiogalactopyranoside $(0.2 \mathrm{mM})$. Plasmids were isolated from the Lac $^{-}$transformants, digested with NotI, EcoRI, HindIII, PstI or BglII, subjected to agarose gel electrophoresis to establish fragment size, and used as the Not I linking clones.

Southern hybridization. DNA fragments separated by CHEF were transferred to nitrocellulose membranes (Maniatis et al., 1982). DNA fragments containing a NotI restriction site were isolated from an agarose gel, and labelled by the random-oligonucleotide priming method (Feinberg \& Vogelstein, 1983) using deoxycytidine $5^{\prime}-\alpha-\left[{ }^{32} \mathrm{P}\right]$ triphosphate $\left(\left[{ }^{32} \mathrm{P}\right] \mathrm{dCTP}\right.$, Amersham). Hybridization on nitrocellulose membranes was as described previously (Maniatis et al., 1982; Okahashi et al., 1989a).

$D N A$ probes of the virulence-associated genes of $S$. mutans. The $1.5 \mathrm{~kb}$ PstI fragment of the pac gene for the high-molecular-mass protein antigen (PAc) of serotype $c S$. mutans cloned by Okahashi et al. (1989a) was used as a probe. Probes for the gtfB gene coding for glucosyltransferase B (Shiroza et al., 1987), the $\mathrm{ft} f$ gene coding for fructosyltransferase (Shiroza \& Kuramitsu, 1988), the $\operatorname{scr} B$ gene coding for sucrose-6-phosphate hydrolase (Sato \& Kuramitsu, 1988) and the wapA gene coding for wall-associated protein antigen A (Ferretti et al., 1989) were amplified by the polymerase chain reaction (PCR; Saiki et $a l ., 1985)$. The primers used in the PCR were as follows: $g t f B$ [primer I, 5'-GAATTCCTTTTGGCCAAC; primer II, 5'-GGATCCCCTTAGCAGCTT; (positions 1921 to 2131; Shiroza et al., 1987)], ftf [primer I, 5'-CTCGAGCGACCCAATGTG; primer II, 5'-GAATTCTTACCTTTACCTG; (positions 2178 to 2509; Shiroza \& Kuramitsu,
1988)], $s c r B$ [primer I, 5'-ACAGGTACAGTCCTTTA; primer II, 5'-ACGATTGACATACTTTG; (positions 499 to 946; Sato \& Kuramitsu, 1988)], wapA [primer I, 5'-GGTACAGCACTTTCTAA; primer II, 5'-CAACATCAGTCAAAGTC; (positions 500 to 1016; Ferretti et al., 1989)]. These probes were radiolabelled as described above.

\section{Results}

\section{OFAGE separation of NotI fragments}

For constructing a physical map of the $S$. mutans genome, restriction enzymes that yielded a small number of fragments were sought. Since the $\mathrm{G}+\mathrm{C}$ content of $S$. mutans is $36-38 \%$ (Hamada \& Slade, 1980), enzymes with GC-rich recognition sites such as NotI (GCGGCCGC), SfiI (GGCCN ${ }_{5}$ GGCC), ApaI (GGGCCC), NaeI (GCCGGC), SmaI (CCCGGG) and SacII (CCGCGG) were tested. NotI produced 10 fragments from the $S$. mutans MT8148 genome, ApaI more than 15 fragments, and $\mathrm{NaeI}$ and SacII more than 30 fragments. The sizes of almost all of the fragments ranged from 50 to $100 \mathrm{~kb}$. $S f i \mathrm{I}$ and $S m a \mathrm{I}$ produced no clear fragments (data not shown). NotI was used for further studies since it resulted in the smallest number of fragments.

Fig. 1 shows a representative result of OFAGE separation of NotI fragments of genomes of $S$. mutans MT8148, S. mutans GS-5 and S. sobrinus 6715. OFAGE was carried out at various pulse times to determine the sizes of the Not $\mathrm{I}$ fragments. To check for the existence of fragments smaller than $20 \mathrm{~kb}$, nonpulsed $0.7 \%$ agarose gels of the digests ( $10 \mu \mathrm{g}$ of DNA) were also run (data not shown). A summary diagram of the gel patterns is shown in Fig. 2. The NotI fragments of $S$. mutans MT8148 genome were named A through J in order of size (Fig. 2). From summation of lengths of the Not $\mathrm{I}$ fragments, the sizes of the $S$. mutans and $S$. sobrinus chromosomes were estimated to be about $2200 \mathrm{~kb}$ (Table 1).

\section{Construction of a NotI restriction map}

To generate a physical map of the $S$. mutans MT8148 genome, we used two procedures: (i) Southern blotting with NotI linking probes that were selected to prove the contiguity of two fragments (Smith et al., 1987); and (ii) partial NotI digestion (Smith et al., 1987).

To isolate Not I linking clones, the chromosomal DNA of $S$. mutans MT8148 was digested with EcoRI, HindIII, PstI or $B g l \mathrm{II}$, and self-ligated. The ligated fragments were digested with NotI, and ligated to the NotI-digested plasmid vector pBlueScript II. The NotI restriction sites 


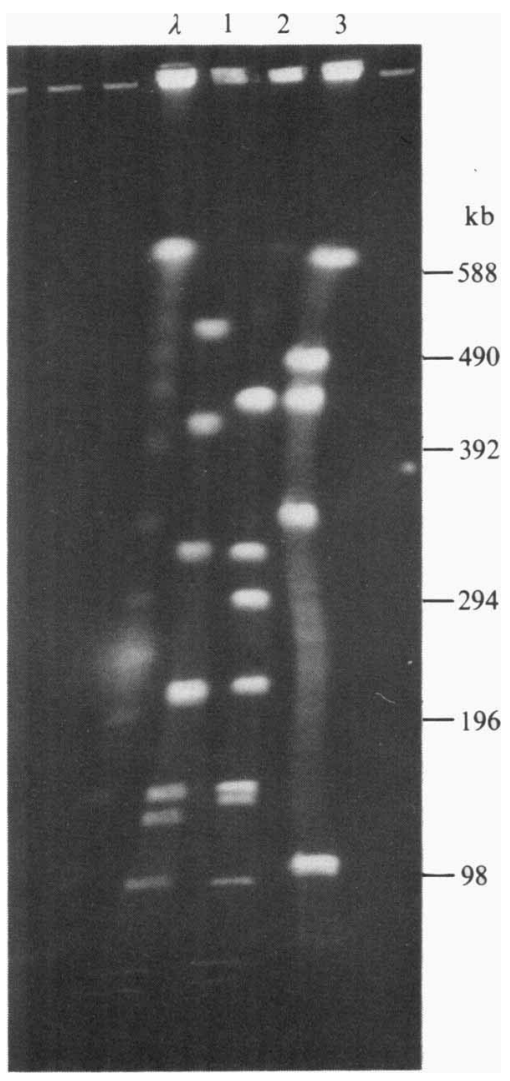

Fig. 1. Banding pattern after OFAGE of the NotI digests of $S$. mutans and $S$. sobrinus genomes. The pulse times were $10 \mathrm{~s}$ for $10 \mathrm{~h}, 30 \mathrm{~s}$ for $22 \mathrm{~h}$, and then $50 \mathrm{~s}$ for $10 \mathrm{~h}$. Lanes: $\lambda, \lambda$ ladder; $1, S$. mutans MT8148; 2, S. mutans GS-5; 3, S. sobrinus 6715.

on the cloned fragments were determined by mapping with NotI, EcoRI, HindIII, PstI and BglII (data not shown). An example of Southern blot analysis probed with the linking clones is shown in Fig. 3. The linking analysis by using many Not I linking clones revealed that the NotI fragments of the $S$. mutans MT8148 genome were arranged in the following order: F-A-G-H-J-C-B-D-I.

In this study, clones linking fragment $\mathrm{E}$ could not be obtained, although this fragment was expected to be located between $F$ and $I$ from the above results. To confirm the location of fragment E, partial NotI digests were analysed by hybridization with cloned probes. A D-specific probe and an I-specific probe were prepared from a linking clone that hybridized both fragments D and I. The Southern blotting showed that the fragments were arranged in the expected order:-D-I-E-F- (Fig. 4). This finding was also confirmed by Southern blot analysis with an F-specific probe (data not shown). These results positioned ten NotI fragments of the $S$. mutans MT8148 genome as shown in Fig. 5.

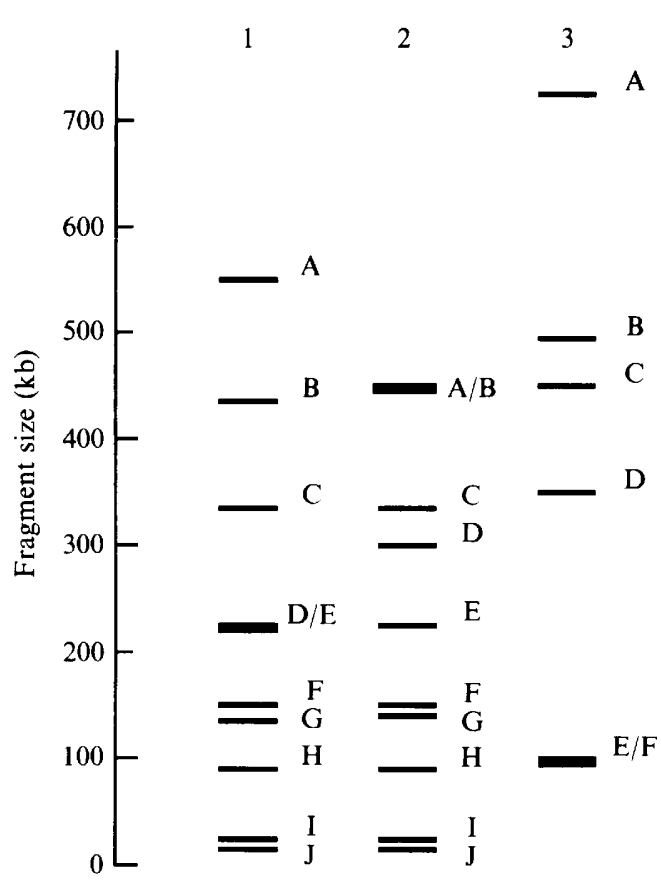

Fig. 2. Idealized gel band plot of the Not I restriction fragments. Lanes: 1, S. mutans MT8148; 2, S. mutans GS-5; 3, S. sobrinus 6715.

Table 1. Sizes of NotI restriction fragments of S. mutans MT8148, S. mutans GS-5 and S. sobrinus 6715

\begin{tabular}{cccc}
\hline \hline & \multicolumn{3}{c}{ Fragment size (kb) } \\
\cline { 2 - 4 } Fragment & $\begin{array}{c}\text { S. mutans } \\
\text { MT8148 }\end{array}$ & $\begin{array}{c}\text { S. mutans } \\
\text { GS-5 }\end{array}$ & $\begin{array}{c}\text { S. sobrinus } \\
6715\end{array}$ \\
\hline A & 550 & 450 & 750 \\
B & 430 & 450 & 490 \\
C & 330 & 330 & 450 \\
D & 220 & 300 & 340 \\
E & 220 & 220 & 100 \\
F & 150 & 150 & 100 \\
G & 130 & 140 & \\
H & 90 & 90 & \\
I & 25 & 25 & 2230 \\
J & 20 & 20 & \\
Total & 2165 & 2175 & \\
\hline \hline
\end{tabular}

Placement of genetic markers on the NotI map

We used Southern blotting to map five virulenceassociated genes on the NotI restriction map. Probes for the pac, gtf $B, f t f, \operatorname{scr} B$ and wap $A$ genes hybridized to the $\mathrm{G}, \mathrm{C}, \mathrm{E}, \mathrm{E}$ and $\mathrm{C}$ fragments, respectively, of the S. mutans MT8148 genome (Table 2).

Comparison of NotI restriction patterns of various strains of $S$. mutans

As shown in Fig. 1, the fragment patterns of the Not I digests of the $S$. mutans MT8148 and GS-5 genomes were 


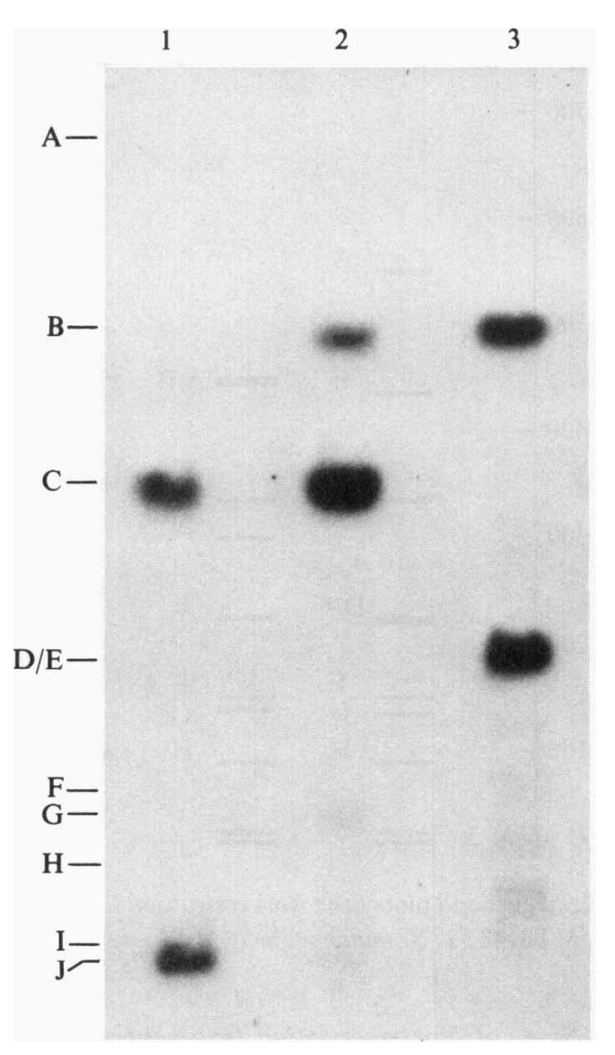

Fig. 3. An example of Southern blot analysis of the $S$. mutans MT8148 genome using the Not $\mathrm{I}$ linking clones. Fragments from Not $\mathrm{I}$ linking clones were radiolabelled and used as probes in blot hybridization experiments on CHEF-separated Not I digests. Lanes: 1 , probed with a J-Clinking clone; 2 , probed with a C-B linking clone; 3 , probed with a B-D linking clone. Positons of the Not I fragments of the $S$. mutans genome are indicated on the left. The results indicate the fragment order $\mathbf{J}-\mathbf{C}-\mathbf{B}-\mathbf{D}$.

not identical, suggesting that OFAGE may be useful for chromosomal DNA fingerprinting. Therefore, chromosomal DNAs of various strains of serotype $c S$. mutans were digested with $N o t \mathrm{I}$, and analysed by OFAGE. S. mutans strains MT6801, MT6861 and MT6879, which form large mucoid colonies on mitis-salivarius agar, were isolated from a mother and her two daughters. Their unique colony morphology has been thought to be evidence of the intrafamilial transmission of $S$. mutans (Okahashi et al., 1984). The NotI restriction patterns of strains MT6801, MT6861 and MT6879 were identical (Fig. 6). On the other hand, S. mutans Xc100L was isolated from a 100 -fold subculture of strain Xc, a freshly isolated strain of serotype $c$ S. mutans (Koga et al., 1989). The parent strain Xc is hydrophobic, and strain Xc100L was a relatively hydrophilic variant (Koga et al., 1989). The NotI restriction patterns of strain Xc and Xc100L were essentially identical (Fig. 6). However, the patterns of MT8148, Xc and MT6801 (and GS-5: see Fig. 1) were different from one another.
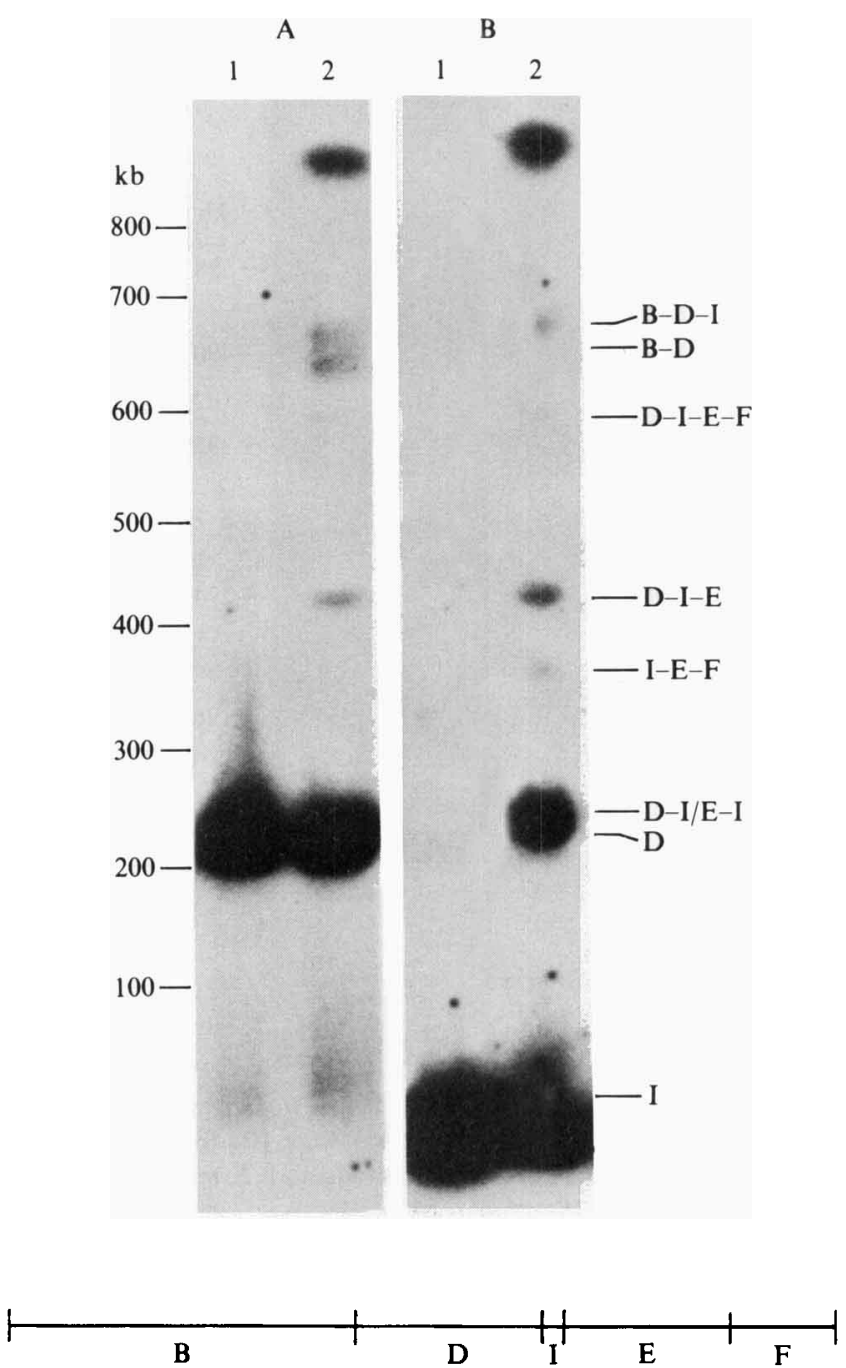

Fig. 4. Southern blot analysis of complete and partial digests of the $S$. mutans MT8148 genome with NotI. Blots of complete (lane 1) and partial (lane 2) NotI digests of the $S$. mutans MT8148 genome were probed with (A) D-specific probe, and (B) I-specific probe. The interpretation of the digestion pattern is shown at the bottom.

Table 2. Placing of genetic markers on the restriction map of the $S$. mutans MT8148 genome

Markers were mapped by Southern hybridization.

\begin{tabular}{lcl}
\hline \hline Marker & NotI fragment & \multicolumn{1}{c}{ Reference } \\
\hline pac & $\mathrm{G}$ & Okahashi et al. (1989a) \\
gtf $B$ & $\mathrm{C}$ & Shiroza et al. (1987) \\
ftf & $\mathrm{E}$ & Shiroza \& Kuramitsu (1988) \\
scr $B$ & $\mathrm{E}$ & Sato \& Kuramitsu (1988) \\
wapA & $\mathrm{C}$ & Ferretti et al. (1989) \\
\hline \hline
\end{tabular}

\section{Discussion}

In the present study, the restriction enzyme NotI was found to produce distributions of DNA fragment size 


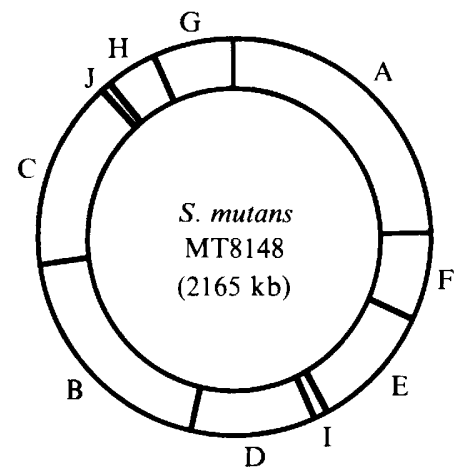

Fig. 5. NotI restriction map of the $S$. mutans MT8148 genome.

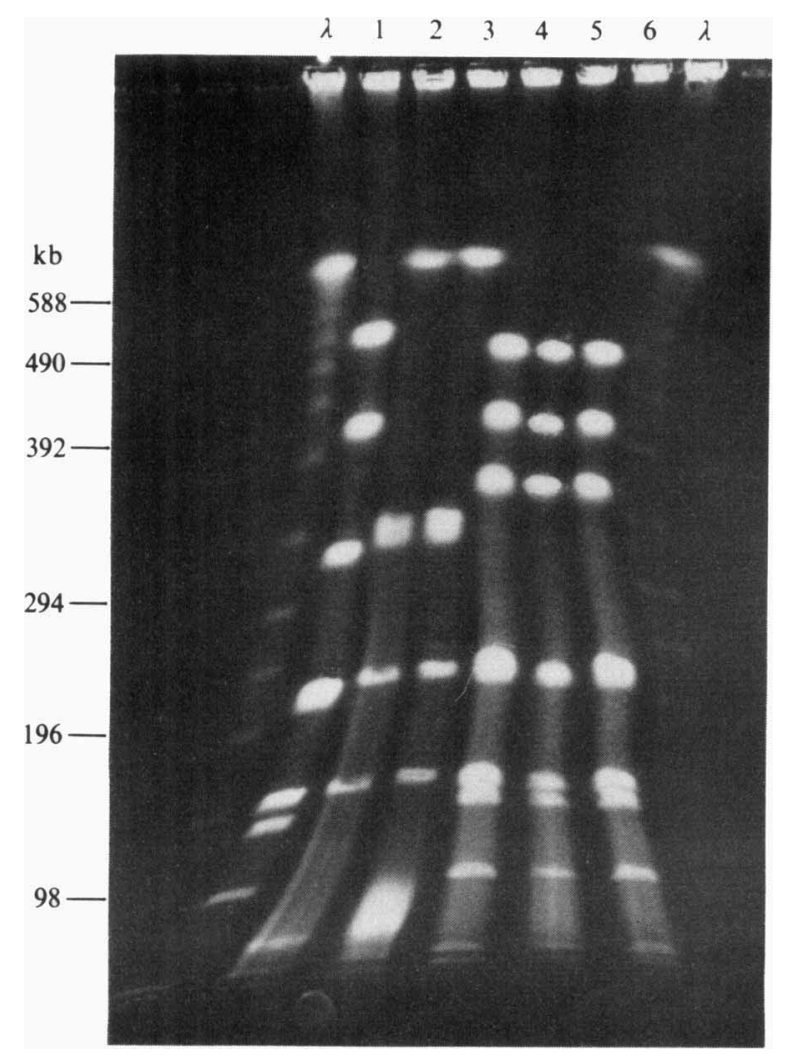

Fig. 6. OFAGE analysis of NotI digests of DNAs from $S$. mutans strains. Lanes: $\lambda, \lambda$ ladder; $1, S$. mutans MT8148; $2, S$. mutans Xc; 3, S. mutans Xc100L; 4, S. mutans MT6801; 5, S. mutans MT6861; 6, S. mutans MT6879. Running conditions were as in Fig. 1.

useful for mapping of the genomes of $S$. mutans and $S$. sobrinus by PFG. Although we may have missed some very small fragments, since ethidium bromide searches alone are not likely to reveal all such fragments, the genome sizes of $S$. mutans MT8148 and GS-5 and $S$. sobrinus 6715 determined by PFG analysis were estimated to be about $2200 \mathrm{~kb}$. Results of PFG of NotI digests of $S$. mutans strains MT6801 and Xc suggested that the genome sizes of these strains were also around $2200 \mathrm{~kb}$ (Fig. 6). In addition, summation of lengths of ApaI fragments of $S$. mutans MT8148 genome supported our conclusion (data not shown). These sizes are very similar to the genome sizes $(1800-2500 \mathrm{~kb})$ of Lactococcus and Streptococcus species reported by Bourgeois et al. (1989). These results suggest that the genome sizes of streptococci are smaller than that of $E$. coli $(4700 \mathrm{~kb})$ (Smith et al., 1987). On the other hand, the genome of Haemophilus influenzae has been reported to be of the same magnitude as that of $S$. mutans (Kauc et al., 1989; Lee et al., 1989). Recently, Tudor et al. (1990) reported that the size of the $S$. mutans GS-5 genome is $2800 \mathrm{~kb}$. Their size estimate is larger than that obtained in this study. This discrepancy might result from divergence or deletion in the $S$. mutans genome on prolonged laboratory culture.

The restriction map of $S$. mutans MT8148 constructed here is one of a few complete bacterial restriction maps (Bautsch, 1988; Canard \& Cole, 1989; Ely \& Gerardot, 1988; Kauc et al., 1989; Lee et al., 1989; Smith et al., 1987) demonstrated by PFG. Although only one restriction enzyme, Not $I$, was used for mapping, in the present study, this map will be useful for both physical and genetic analyses of the $S$. mutans genome.

Perry \& Kuramitsu (1989) recently demonstrated that the $g t f A$ (a gene coding for glucosyltransferase A), $s c r B$ and $f t f$ genes are clustered on the $S$. mutans chromosome, with $f t f$ located between $g t f A$ and $s c r B$. They showed that the cotransfer system used in their study is efficient for mapping closely linked markers (Perry et al., 1985). However, the system seems to be unsuitable for large-scale mapping. In the present study, the pac, gtf $B$, $f t f, \operatorname{scr} B$ and wapA genes were placed on the Not I restriction map. The $f t f$ and $\operatorname{scr} B$ genes were located on the same NotI fragment, E (Table 2): this result supports the finding of Perry \& Kuramitsu (1989) that the two genes are closely linked. It will also be possible to locate other genes on the restriction map by Southern hybridization. Procino et al. (1988) have shown that transposon Tn916 can be used to mutagenize $S$. mutans by insertional inactivation and have isolated a variety of different amino acid auxotrophs. This method will also be useful in constructing the $S$. mutans genome map. In addition, our preliminary study showed that the restriction enzyme $A p a I$ produced relatively few fragments (more than 15). We are presently attempting to complete the map of ApaI fragments and to develop a set of mapped cosmid clones covering the entire genome.

Molecular biological methods have recently been applied to type $S$. mutans strains for epidemiological investigations. One of the general and reliable methods is agarose gel electrophoresis analysis of genomic DNA fragments produced by restriction endonucleases 
(Caufield \& Walker, 1989; Kulkarni et al., 1989). However, the commonly used endonucleases produce too many fragments in agarose gel electrophoresis. In contrast, PFG showed relatively simple electrophoretic patterns of genomic DNA digested with NotI (see Figs 1 and 6). This technique will make it easier to compare numerous $S$. mutans strains from various origins.

We thank Drs I. Moro and I. Saito (Nihon University School of Dentistry) for their advice and help in synthesizing probes by PCR, and Dr S. Hamada (Osaka University Faculty of Dentistry) for providing S. mutans strains MT6801, MT6861 and MT6879. This work was supported in part by a Grant-in-Aid for Developmental Scientific Research (no. 63870086) from the Ministry of Education and Culture of Japan and by the Japan Health Sciences Foundation.

\section{References}

Abiko, Y., Hayakawa, M., Aoki, H., Saito, S. \& Takiguchi, H. (1989). Cloning of the gene for cell-surface protein antigen A from Streptococcus sobrinus (serotype $d$ ). Archives of Oral Biology 34, 571-575.

Barrett, J. F., Barrett, T. A. \& Curtiss III, R. (1987). Purification and partial characterization of the multicomponent dextranase complex of Streptococcus sobrinus and cloning of the dextranase gene. Infection and Immunity 55, 792-802.

BAUTSCH, W. (1988). Rapid physical mapping of the Mycoplasma mobile genome by two-dimensional field inversion gel electrophoresis techniques. Nucleic Acids Research 16, 11461-11467.

Bourgeois, P. L., Mata, M. \& Ritzenthaler, P. (1989). Genome comparison of Lactococcus strains by pulsed-field gel electrophoresis. FEMS Microbiology Letters 59, 65-70.

CANARD, B. \& Cole, S. T. (1989). Genome organization of the anaerobic pathogen Clostridium perfringens. Proceedings of the National Academy of Sciences of the United States of America 86, 6676-6680.

Carle, G. F. \& Olson, M. V. (1984). Separation of chromosomal DNA molecules from yeast by orthogonal-field-alternation gel electrophoresis. Nucleic Acids Research 12, 5647-5664.

Caufield, P. W. \& Walker, T. M. (1989). Genetic diversity within Streptococcus mutans evident from chromosomal DNA restriction fragment polymorphisms. Journal of Clinical Microbiology 27, 274-278.

Chu, G., Vollrath, D. \& Davis, R. W. (1986). Separation of large DNA molecules by contour-clamped homogeneous electric fields. Science 234, 1582-1585.

CURTISs, R., III (1986). Genetic analysis of Streptococcus mutans virulence and prospects for an anticaries vaccine. Journal of Dental Research 65, 1034-1045.

ELY, B. \& GERARDOT, C. J. (1988). Use of pulsed-field-gradient gel electrophoresis to construct a physical map of the Caulobacter crescentus genome. Gene 68, 323-333.

Feinberg, A. P. \& Vogelstein, B. (1983). A technique for radiolabelling DNA restriction endonuclease fragments to high specific activity. Analytical Biochemistry 132, 6-13.

FerRetti, J. J., Gilpin, M. L. \& Russell, R. R. B. (1987). Nucleotide sequence of a glucosyltransferase gene from Streptococcus sobrinus MFe28. Journal of Bacteriology 169, 4271-4278.

Ferretti, J. J., Huang, T.-T. \& Russell, R. R. B. (1988). Sequence analysis of the glucosyltransferase A gene ( $\mathrm{gtf} A$ ) from Streptococcus mutans Ingbritt. Infection and Immunity 56, 1585-1588.

FerRetTI, J. J., Russell, R. R. B. \& Dao, M. L. (1989). Sequence analysis of the wall-associated protein precursor of Streptococcus mutans antigen A. Molecular Microbiology 3, 469-478.
Hamada, S. \& Slade, H. D. (1980). Biology, immunology and cariogenicity of Streptococcus mutans. Microbiological Reviews 44, 331-384.

Hanada, N. \& KuRamitsu, H. K. (1989). Isolation and characterization of the Streptococcus mutans gtf $D$ gene, coding for primerdependent soluble glucan synthesis. Infection and Immunity 57, 2079-2085.

KaUC, L., Mitchell, M. \& Goodgal, S. H. (1989). Size and physical map of the chromosome of Haemophilus influenzae. Journal of Bacteriology 171, 2474-2479.

Koga, T., Asakawa, H., OKahashi, N. \& TaKahashi, I. (1989). Effect of subculturing on expression of a cell-surface protein antigen by Streptococcus mutans. Journal of General Microbiology 135, 3199-3207.

Kulkarni, G. V., Chan, K. H. \& Sandham, H. J. (1989). An investigation into the use of restriction endonuclease analysis for the study of transmission of mutans streptococci. Journal of Dental Research 68, 1155-1161.

KuRAmitsu, H. K. (1987). Recent advances in defining the cariogenicity of mutans streptococci: molecular genetic approaches. European Journal of Epidemiology 3, 257-260.

Lee, S. F., Progulske-Fox, A. \& Bleiweis, A. S. (1988). Molecular cloning and expression of a Streptococcus mutans major surface protein antigen, $\mathrm{P} 1$ (I/II), in Escherichia coli. Infection and Immunity 56, 2114-2119.

LeE, J. J., Smith, H. O. \& Redfield, R. J. (1989). Organization of the Haemophilus influenzae Rd genome. Journal of Bacteriology 171 , 3016-3024

LOESCHE, W. J. (1986). Role of Streptococcus mutans in human dental decay. Microbiological Reviews 50, 353-380.

LUNSFORD, R. D. \& MACRINA, F. L. (1986). Molecular cloning and characterization of $s c r B$, the structural gene for the Streptococcus mutans phosphoenolpyruvate-dependent sucrose phosphotransferase system sucrose-6-phosphate hydrolase. Journal of Bacteriology 166 426-434.

Maniatis, T., Fritsch, E. F. \& Sambrook, J. (1982). Molecular Cloning: a Laboratory Manual. Cold Spring Harbor, NY: Cold Spring Harbor Laboratory.

OgUNDIPE, J. O. \& Holt, R. G. (1989). Molecular and immunochemical characterization of recombinant Escherichia coli containing the spaA gene region of Streptococcus sobrinus. Infection and Immunity 57, 1906-1915.

Ohta, H., Kato, H., OKahashi, N., Takahashi, I., Hamada, S. \& KOGA, T. (1989). Characterization of a cell-surface protein antigen of hydrophilic Streptococcus mutans strain GS-5. Journal of General Microbiology 135, 981-988.

Orahashi, N., Asakawa, H., Koga, T., Masuda, N. \& Hamada, S. (1984). Clinical isolates of Streptococcus mutans serotype $c$ with altered colony morphology due to fructan synthesis. Infection and Immunity 44, 617-622.

Okahashi, N., Sasakawa, C., Yoshixawa, M., Hamada, S. \& Koga, T. (1989 $a$ ). Cloning of a surface protein antigen gene from serotype $c$ Streptococcus mutans. Molecular Microbiology 3, 221-228.

Okahashi, N., Sasakawa, C., Yoshixawa, M., Hamada, S. \& Koga, T. (1989b). Molecular characterization of a surface protein antigen gene from serotype $c$ Streptococcus mutans, implicated in dental caries. Molecular Microbiology 3, 673-678

Perry, D., Nilsen, L. J. \& Kuramitsu, H. K. (1985). Mapping of a cloned glucosyltransferase gene in Streptococcus mutans. Infection and Immunity 50, 130-135.

Perry, D. \& Kuramitsu, H. K. (1989). Genetic linkage among cloned genes of Streptococcus mutans. Infection and Immunity 57, 805-809.

Procino, J. K., Marri, L., Shockman, G. D. \& Daneo-Moore, L. (1988). Tn916 insertional inactivation of multiple genes on the chromosome of Streptococcus mutans GS-5. Infection and Immunity 56, 2866-2870.

Saiki, R. K., Scharf, S., Faloona, F., Mullis, K. B., Horn, G. T., ERLICH, H. A. \& ARNHEIM, N. (1985). Enzymatic amplification of $\beta$-globin genomic sequences and restriction site analysis for diagnosis of sickle cell anemia. Science 230, 1350-1354. 
Sato, Y. \& Kuramitsu, H. K. (1988). Sequence analysis of the Streptococcus mutans scrB gene. Infection and Immunity 56, 1956-1960.

Schwartz, D. C. \& Cantor, C. R. (1984). Separation of yeast chromosome-sized DNAs by pulsed field gradient gel electrophoresis. Cell 37, 67-75.

Shiroza, T. \& Kuramitsu, H. K. (1988). Sequence analysis of the Streptococcus mutans fructosyltransferase gene and flanking regions. Journal of Bacteriology 170, 810-816.

Shiroza, T., UEDA, S. \& KurAmitsu, H. K. (1987). Sequence analysis of the gtf $B$ gene from Streptococcus mutans. Journal of Bacteriology 169, 4263-4270.

Smith, C.L., Econome, J. G., Schutt, A., Klco, S. \& Cantor, C. R. (1987). A physical map of the Escherichia coli K 12 genome. Science 236, 1448-1453.
Smith, C. L. \& Cantor, C. R. (1987), Purification, specific fragmentation, and separation of large DNA molecules. Methods in Enzymology 155, 449-467.

SOMmer, P., BruYere, T., Ogier, J. A., Garnier, J.-M., Jeltsch, J.-M. \& KLEIN, J.-P. (1987). Cloning of the saliva-interacting protein gene from Streptococcus mutans. Journal of Bacteriology 169, $5167-5173$.

Takahashi, I., OKahashi, N., Sasakawa, C., Yoshikawa, M., HAMADA, S. \& KOGA, T. (1989). Homology between surface protein antigen genes of Streptococcus sobrinus and Streptococcus mutans. FEBS Letters 249, 383-388.

Tudor, J. J., Marri, L., Piggot, P. J. \& Daneo-Moore, L. (1990). Size of the Streptococcus mutans GS- 5 chromosome as determined by pulsed-field gel electrophoresis. Infection and Immunity 58, 838-840.

Ueda, S., Shiroza, T. \& Kuramitsu, H. K. (1988). Sequence analysis of the gtfC gene from Streptococcus mutans GS-5. Gene 69, 101-109. 